\title{
Development of the spectrophotometric method for the quantitative determination of phenolic compounds calculated with reference to 6-gingerol in tablets based on a dry ginger extract
}

Zingiber officinale has a wide range of pharmacological properties, including hypoglycemic and antioxidant ones. Most literature sources associate the pharmacological activity and mechanism of action of ginger with the content of phenolic compounds, and in particular gingerol.

Aim. To develop the spectrophotometric method for the quantitative determination of the total amount of phenolic compounds calculated with reference to 6-gingerol in tablets based on a dry ginger extract.

Materials and methods. The study object were tablets with an average weight of $0.5 \mathrm{~g}$ containing $0.3 \mathrm{~g}$ of a dry ginger extract (manufacturer - "Medagroprom", Dnipro) obtained by the direct compression method. The spectrophotometric method was used to determine phenolic compounds calculated with reference to 6-gingerol.

Results and discussion. The spectral characteristics of a standard sample of 6-gingerol, a predominant substance among biologically active phenolic compounds of ginger, have been studied. It has been shown that its absorption spectrum in the range from 220 to $400 \mathrm{~nm}$ contains one absorption band with a maximum at $281 \mathrm{~nm}$, which can be used as an analytical absorption band for the quantitative determination by absorption spectrophotometry. It has been proven that excipients do not interfere with the quantitative determination of the total amount of phenolic compounds in the composition of tablets with a dry extract of ginger since they do not absorb electromagnetic radiation in the region of the analytical maximum. It has been found that the content of the total amount of phenolic compounds calculated with reference to 6-gingerol in the experimental batch of tablets is $0.03556 \pm 0.0088 \mathrm{~g} / \mathrm{tab}$. The relative uncertainty of the mean determination was $1.007 \%$.

Conclusions. The spectrophotometric method for the quantitative determination of the total amount of phenolic compounds calculated with reference to 6-gingerol in tablets based on a dry ginger extract with the subsequent calculation by the standard method has been developed. It can be used to develop quality control procedures for the tablets under research.

Key words: spectrophotometer; dry extract; ginger; tablets; gingerol; diabetes mellitus

В. А. Алхалафр Малек, В. О. Грудько, О. А. Рубан, Н. А. Гербіна, О. В. Гвоздик

Національний фармацевтичний університет Міністерства охорони здоров'я України

Розробка спектрофотометричної методики кількісного визначення суми фенольних сполук у перерахунку на 6-гінгерол у таблетках на основі сухого екстракту імбиру лікарського

Імбир лікарський має широкий спектр фармакологічних властивостей, серед яких гіпоглікемічні та антиоксидантні. Більшість літературних джерел пов'язує фрармакологічну активність та механізм дії імбиру з вмістом у ньому фенольних сполук, зокрема гінгеролу.

Метою даної роботи є розробка спектрофотометричної методики кількісного визначення суми фенольних сполук у перерахунку на 6-гінгерол у таблетках на основі сухого екстракту імбиру лікарського.

Матеріали та методи. Об'єктом дослідження були таблетки, отримані методом прямого пресування з середньою масою 0,5 г, що містять 0,3 г сухого екстракту імбиру лікарського (виробник «Медагропром», м. Дніпро). Для визначення фенольних сполук у перерахунку на 6-гінгерол використовували спектрофотометричну методику.

Результати та їх обговорення. Вивчені спектральні характеристики стандартного зразка 6-гінгеролу, який $€$ переважаючою речовиною серед біологічно активних фенольних сполук імбиру лікарського. Показано, що у його абсорбційному спектрі в області від 220 до 400 нм міститься одна смуга поглинання з максимумом при 281 нм, яка може бути використана як аналітична смуга вбирання для кількісного визначення методом абсорбційної спектрофотометрії. Доведено, що допоміжні речовини не заважають кількісному визначенню суми френольних сполук у складі таблеток з сухим екстрактом імбиру, оскільки не поглинають електромагнітного випромінювання в області аналітичного максимуму. Встановлено, що вміст суми фенольних сполук у перерахунку на 6-гінгерол в експериментальній серії таблеток складає 0,03556 0 0,0088 г/т. Відносна невизначеність середнього визначення склала $1,007 \%$.

Висновки. Розроблено спектрофотометричну методику кількісного визначення суми фенольних сполук у перерахунку на 6-гінгерол у таблетках на основі сухого екстракту імбиру лікарського з наступним розрахунком за методом стандарту, яка може бути використана при розробці методик контролю якості досліджуваних таблеток.

Ключові слова: спектрофотометр; сухий екстракт; імбир; таблетки; гінгерол; цукровий діабет 
В. А. Алхалаф Малек, В. А. Грудько, Е. А. Рубан, Н. А. Гербина, О. В. Гвоздик

Национальный фрармацевтический университет Министерства здравоохранения Украины

\title{
Разработка спектрофотометрической методики количественного определения суммы фенольных соединений в пересчете на 6-гингерол в таблетках на основе сухого экстракта имбиря лекарственного
}

\begin{abstract}
Имбирь лекарственный имеет широкий спектр фармакологических свойств, среди которых гипогликемические и антиоксидантные. Большинство литературных источников связывает фрармакологическую активность и механизм действия имбиря с содержанием в нем фенольных соединений и в частности гингерола.

Целью данной работы является разработка спектрофотометрической методики количественного определения суммы фенольных соединений в пересчете на 6-гингерол в таблетках на основе сухого экстракта имбиря лекарственного.

Материалы и методы. Объектом исследования были таблетки, полученные методом прямого прессования со средней массой 0,5 г, содержащие 0,3 г сухого экстракта имбиря лекарственного (производитель «Медагропром», г. Днепро). Для определения фенольных соединений в пересчете на 6-гингерол использовали спектрофротометрическую методику.

Результаты и их обсуждение. Изучены спектральные характеристики стандартного образца 6-гингерола, который является преобладающим веществом среди биологически активных фенольных соединений имбиря лекарственного. Показано, что в его абсорбционном спектре в области от 220 до 400 нм содержится одна полоса поглощения с максимумом при 281 нм, которая может быть использована как аналитическая полоса поглощения для количественного определения методом абсорбционной спектрофотометрии. Доказано, что вспомогательные вещества не мешают количественному определению суммы фенольных соединений в составе таблеток с сухим экстрактом имбиря, поскольку не поглощают электромагнитные излучения в области аналитического максимума. Установлено, что содержание суммы фенольных соединений в пересчете на 6-гингерол в экспериментальной серии таблеток составляет 0,03556 \pm 0,0088 г/т. Относительная неопределенность среднего определения составила 1,007 \%.

Выводы. Разработана спектрофотометрическая методика количественного определения суммы фенольных соединений в пересчете на 6-гингерол в таблетках на основе сухого экстракта имбиря лекарственного с последующим расчетом по методу стандарта, которая может быть использована при разработке методик контроля качества исследуемых таблеток.
\end{abstract}

Ключевые слова: спектрофотометр; сухой экстракт; имбирь; таблетки; гингерол; сахарный диабет

Introduction. Ginger (Zingiber officinale Roscoe) is a perennial herbaceous plant of the Zingiberaceae family. It is cultivated in many tropical and subtropical countries, including Australia, Nigeria and Haiti; moreover, China and India are the world's leading producers of ginger.

In folk medicine, ginger is used to treat colds, rheumatism, angina, and digestive disorders, such as dyspepsia, nausea, vomiting, gastritis, and diarrhoea. Lately, ginger has attracted attention because of its wide range of pharmacological activities, such as antitumor, antioxidant, anti-inflammatory, anti-diabetic, cytotoxic, antiplatelet ones [1].

The main bioactive components of ginger are essential oils, as well as phenolic compounds, such as gingerol and shogaol, which are responsible for the particular pungent taste of the plant. The preliminary pharmacological studies have made it possible to associate the hypoglycemic and antioxidant activity of a dry ginger extract with the 6-gingerol content $[2,3]$. This confirms the relevance and prospects of its use for the development of hypoglycemic drugs [4].

To determine the total amount of phenolic compounds, which 6-gingerol belongs to, in herbal medicines, the spectrophotometric analysis is widely used [5].

Therefore, the aim of this work was to develop the spectrophotometric method for the quantitative determination of the total amount of phenolic compounds calculated with reference to 6-gingerol in tablets based on a dry ginger extract.

Materials and methods. The study objects were tablets with an average weight of $0.5 \mathrm{~g}$, containing $0.3 \mathrm{~g}$ of a dry extract of ginger (manufacturer - "Medagroprom", Dnipro). They were obtained by the direct compression method [6].

The solution of 6-gingerol by HPLC (manufactured by Aktin chemicals, Inc., China) was used as the standard solution.

On the basis of the previous studies of a dry ginger extract the optimal solvent - $40 \%$ ethyl alcohol - was selected; it allowed the maximum extraction of pharmacologically active amount of phenolic compounds from the dry extract composition [7].

To quantify the total amount phenolic compounds calculated with reference to 6-gingerol in tablets the test solution, placebo solution and comparison solution were prepared.

Test solution and placebo solution. Place approximately $0.15 \mathrm{~g}$ of the powdered tablets or $0.06 \mathrm{~g}$ of the powdered mixture of excipients (accurate weight) in a $50 \mathrm{ml}$ volumetric flask and add $30 \mathrm{ml}$ of $40 \%$ ethanol. After heating on a water bath, stirring and subsequent cooling dilute the solution to the volume with the same solvent. Filter the resulting solutions through a "blue ribbon" paper filter removing the first $5 \mathrm{ml}$ of the filtrates. Place $5 \mathrm{ml}$ of the solutions' filtrates in $25 \mathrm{ml}$ flasks and dilute to the volume with ethanol $40 \%$ while stirring.

Comparison solution. Place $100 \mathrm{mg}$ of the standard sample of 6-gingerol in a $50 \mathrm{ml}$ volumetric flask, dilute the solution to the volume with $96 \%$ ethanol and mix. After that place $1 \mathrm{ml}$ of the initial solution of gingerol in a $50 \mathrm{ml}$ volumetric flask, dilute to the volume with $40 \%$ ethanol and mix. 


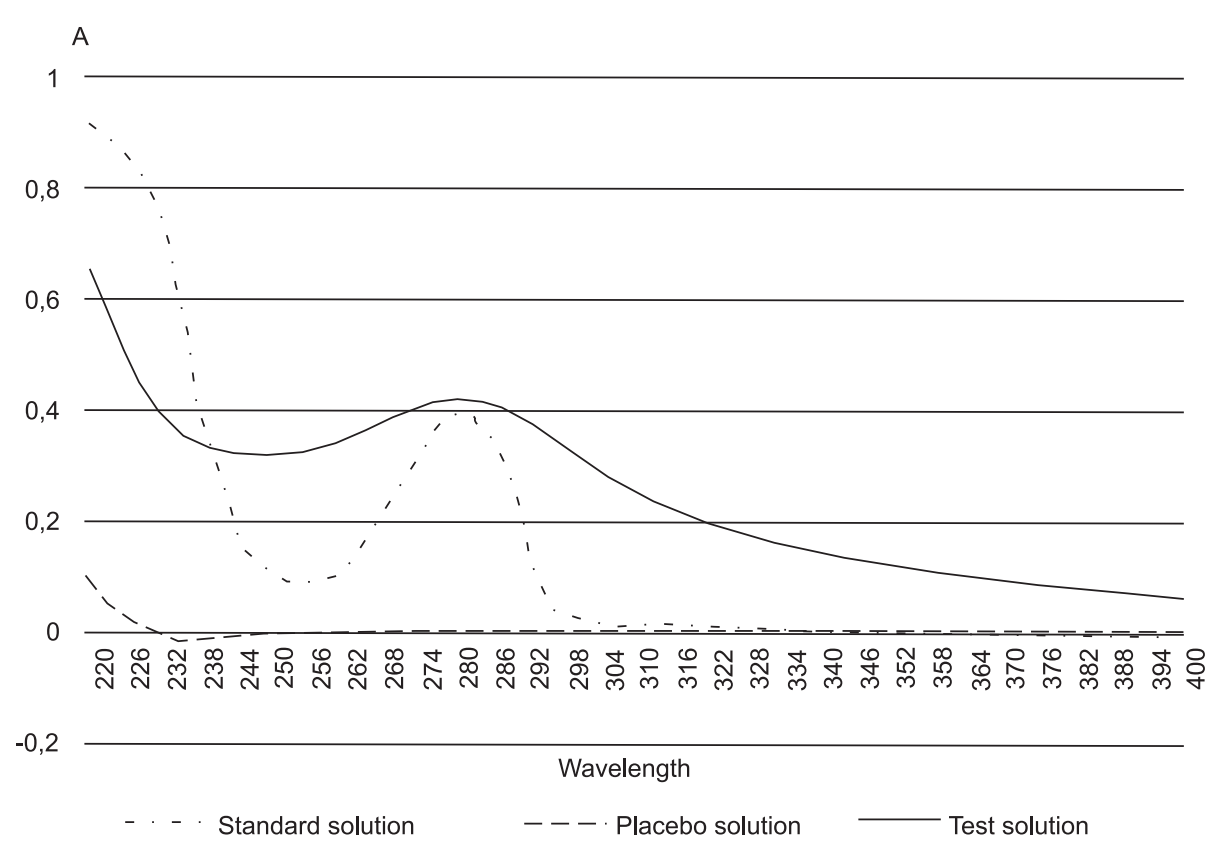

Fig. Absorption spectra of 6- gingerol, tablet mass and placebo solutions in $40 \%$ ethanol

For the solutions obtained on an Evolution 60-S spectrophotometer the absorption spectra (Fig.) were taken in the range of 220-400 $\mathrm{nm}$, and the optical density was determined at a wavelength of $281 \mathrm{~nm}$ in cells with a layer thickness of $10 \mathrm{~mm}$. As the control solution $40 \%$ ethanol was used.

Results and discussion.As can be seen in Fig., the absorption maxima of the standard 6-gingerol solution and the test solution of tablets with a dry ginger extract completely coincide in the absorption spectra of the solutions analyzed in the range from 220 to $400 \mathrm{~nm}$. They contain one absorption band in the region where the aromatic compounds usually absorb with a maximum at $281 \mathrm{~nm}$. The absorption band of the tablet mass solution is much wider, indicating the presence of the total amount of phenolic compounds with the similar structure. The coincidence of maxima indicates the possibility of their total quantitative determination with conditional calculation to 6-gingerol. The placebo solution does not absorb ultraviolet radiation in the region specified and thus cannot affect the results of the spectrophotometric quantitative determination of the total amount of biologically active compounds.
According to the results of determining the optical density of the test solutions and comparison solutions, the content of phenolic compounds in one tablet (in grams) calculated with reference to 6 -gingerol was found by the formula:

$$
X_{\frac{g}{t}}=\frac{A \times V_{1} \times V_{3} \times m_{s t} \times V_{2 s t} \times m_{t}}{A_{s t} \times m_{s} \times V_{2} \times V_{1 s t} \times V_{3 s t}},
$$

where: $A_{s t}$ - is the optical density of the standard solution; $A-$ is the optical density of the test solution; $V_{1}$ - is the volume of the first volumetric flask for preparation of the test solution; $V_{1 s t}$ - is the volume of the first measuring flask for preparation of the standard solution; $V_{2}$-is the volume of the aliquot when preparing the test solution; $V_{2 s t}-$ is the volume of the aliquot when preparing the standard solution; $V_{3}-$ is the volume of the second dilution of the test solution; $V_{3 s t}$ - is the volume of the second dilution of the standard solution; $m_{s}-$ is the sample weight of powdered tablets; $m_{s t}$ - is the weight of the standard 6-gingerol sample; $m_{t}-$ is the average weight of a tablet.

The results are shown in Tab. 1.

Table 1

The results of the quantitative determination of the experimental samples of tablets with a dry ginger extract

\begin{tabular}{|c|c|c|c|}
\hline No & Weight of the sample, g & Optical density, A & $\begin{array}{c}\text { The content of the total amount of phenolic } \\
\text { compounds calculated with reference to } \\
\text { 6-gingerol, g/tablet }\end{array}$ \\
\hline 1 & 0.1449 & 0.417 & 0.03556 \\
\hline 2 & 0.1462 & 0.430 & 0.03637 \\
\hline 3 & 0.1508 & 0.421 & 0.03448 \\
\hline 4 & 0.1496 & 0.427 & 0.03524 \\
\hline 5 & 0.1519 & 0.451 & 0.03669 \\
\hline 6 & 0.1511 & 0.429 & 0.03502 \\
\hline
\end{tabular}

Notes: $A_{s t}=0.398 ; m_{t}-0.4914 \mathrm{~g}$. 
Metrological characteristics of the analysis results

\begin{tabular}{|c|c|c|c|c|c|c|c|}
\hline $\begin{array}{l}\text { The total amount of phenolic } \\
\text { compounds found, } \mathrm{g} / \mathrm{g}\end{array}$ & $\mathrm{X}_{\mathrm{av} \mathrm{v}^{\prime}} \mathrm{g}$ & $S^{2}$ & $S$ & $\mathrm{P}, \%$ & $t(p, f)$ & $\Delta \mathrm{X}_{\mathrm{av}}$ & $\bar{\varepsilon}_{\mathrm{av} v} \%$ \\
\hline 0.03556 & \multirow{6}{*}{0.03556} & \multirow{6}{*}{$6.98 \times 10^{-7}$} & \multirow{6}{*}{0.000836} & \multirow{6}{*}{95} & \multirow{6}{*}{2.57} & \multirow{6}{*}{0.000877} & \multirow{6}{*}{1.007} \\
\hline 0.03637 & & & & & & & \\
\hline 0.03448 & & & & & & & \\
\hline 0.03524 & & & & & & & \\
\hline 0.03669 & & & & & & & \\
\hline 0.03502 & & & & & & & \\
\hline
\end{tabular}

Notes: $\mathrm{S}^{2}$ - dispersion; $\mathrm{S}$ - standard deviation (separate determination); $\mathrm{P}$ - reliability; $\mathrm{t}(\mathrm{p}, \mathrm{f})$-Student's criterion; $\Delta \mathrm{X}_{\mathrm{av}}-$ confidence interval of the mean determination; $\bar{\varepsilon}-$ relative uncertainty of the mean determination, $\%$.

The data obtained were subjected to statistical processing. The results are presented in Tab. 2.

Conclusions and prospects of further research

1. The spectral characteristics of a standard sample of 6-gingerol, a predominant substance among biologically active phenolic compounds of ginger, have been studied. It has been shown that its absorption spectrum in the range from 220 to $400 \mathrm{~nm}$ contains one absorption band with a maximum at $281 \mathrm{~nm}$, which can be used as an analytical absorption band for the quantitative determination by absorption spectrophotometry.

2. It has been proven that excipients do not interfere with the quantitative determination of the total amount of phenolic compounds in the composition of tablets with a dry extract of ginger by the absorption spectrophoto- metry method since they do not absorb electromagnetic radiation in the region of the analytical maximum.

3. The method of the quantitative determination of the total amount of phenolic compounds calculated with reference to 6-gingerol by the method of direct one-wave absorption spectrophotometry with the subsequent calculation by the standard method has been developed.

4. According to the method developed it has been found that the content of the total amount of phenolic compounds calculated with reference to 6-gingerol in the experimental batch of tablets is $0.03556 \pm 0.0088 \mathrm{~g} / \mathrm{tab}$. The relative uncertainty of the mean determination is $1.007 \%$.

Conflict of interests: authors have no conflict of interests to declare.

\section{REFERENCES}

1. Jalal B. Z., Nasroallah M. K. Physiological and pharmaceutical effects of Ginger (Zingiber officinale Roscoe) as a valuable medicinal plant. Euro. J. Exp. Bio. 2014. № 4 (1). P. 87-90.

2. Experimental rationale of selection of the hypoglicemic dose of ginger dry extract on normoglycemic rats / N. M. Kononenko et al. Pharmaceutical Journal. 2018. № 1-2. P. 68-77.

3. Impact of dry extract of ginger on morphological state of pancreas of syrian golden hamsters on the background of hypercalorium diet / N. Kononenko et al. Scientific Journal «ScienceRise: Pharmaceutical Science». 2018. № 4. P. 38-44.

4. Алхалаф М. В. А., Гербина Н. А., Рубан Е. А. Сравнительный маркетинговый анализ сахароснижающих препаратов на рынке Украины и Иордании. Технологічні та біофармацевтичні аспекти створення лікарських препаратів різної направленості дії : матеріали IV Міжнар. наук.-практ. інтернет-конф., м. Харків, 14-15 листоп. 2019 р. Харків : НФаУ, 2019. 248 с.

5. Бельтюкова С. В., Бычкова А. А. Биологически активные полифенолы и методы их определения. Біопроцеси, біотехнологія харчових продуктів, БАР. 2013. № 3 (24). С. 18-25.

6. Substantiation of auxiliary substances of in the composition of tablets with dry extract of zingiber officinale / W. A. Alkhalaf Malek et al. Biopharmaceutical Journal. 2019. № 3. P. 23-28.

7. Визначення фенольних сполук у перерахунку на 6-гінгерол у сухому екстракті імбиру лікарського при розробці таблеток гіпоглікемічної дії / В. А. Алхалаф Малек та ін. Хімія природних сполук : матеріали V Всеукр. наук.-практ. конф. 3 міжнар. участю, м. Тернопіль, 30-31 трав. 2019 р. Тернопіль : ТДМУ, 2019. 174 с.

\section{REFERENCES}

1. Jalal, B. Z., Nasroallah, M. K. (2014). Euro. J. Exp. Bio., 4 (1), 87-90.

2. Kononenko, N. M., Chikitkina, V. V., Sorokina, M. V., Alkhalaf, M. W. (2018). Farmatsevtychnyi zhurnal, 1-2, 68-77.

3. Kononenko, N., Sorokina, M., Larianovska, J., Chikitkina V. (2018). ScienceRise: Pharmaceutical Science, 4, 38-44.

4. Alhalaf, M. V. A., Gerbina, N. A., Ruban, E. A. (2019). Technological and biopharmaceutical aspects of drugs developing with different orientation of action: proceedings of the 4th International Scientific and Practical Internet Conference (14-15.11.2019). (p. 248). Kharkiv.

5. Beltiukova, S. V., Bychkova, A. A. (2013). Bioprotsesy, biotekhnolohiia kharchovykh produktiv, BAR, 3 (24), 18-25.

6. Alkhalaf Malek, W. A., Ruban, O. A., Kutova, O. V., Herbina, N. A. (2019). Biopharmaceutical Journal, 3, $23-28$.

7. Alkhalaf Malek V. A., Hrudko V. O., Ruban E. A., Herbyna N. A. (2019). Chemistry of Natural Compounds: Proceedings of the 5th AllUkrainian Scientific and Practical Conference with International Participation (30-31. 05. 2019). (p. 174). Ternopil. 


\section{Information about authors:}

Alkhalaf Malek W. A., post graduate student of the Department of Industrial Technology of Drugs, National University of Pharmacy of the Ministry of Health of Ukraine. E-mail: malekwalkhalaf@gmail.com. ORCID: http://orcid.org/0000-0003-1188-0632

Ruban O.A., Doctor of Pharmacy (Dr. habil.), professor, head of the Department of Industrial Technology of Drugs, National University of Pharmacy of the Ministry of Health of Ukraine. E-mail: ztl@ukrfa.kharkov.ua. ORCID: https://orcid.org/0000-0002-2456-8210

Grudko V. O., Candidate of Pharmacy (Ph.D.), associate professor of the Department of Pharmaceutical Chemistry, National University of Pharmacy of the Ministry of Health of Ukraine. E-mail: 431230@ukr.net

Herbina N.A., Candidate of Pharmacy (Ph.D.), associate professor of the Department of Industrial Technology of Drugs, National University of Pharmacy of the Ministry of Health of Ukraine. ORCID: https://orcid.org/0000-0001-9826-7552

Gvozdik O. V., Master's degree student of the Department of Pharmaceutical Chemistry, National University of Pharmacy of the Ministry of Health of Ukraine.

\section{Відомості про авторів:}

Алхалаф Малек В. А., аспірант кафедри заводської технології ліків, Національний фармацевтичний університет Міністерства охорони здоров’я України. E-mail: malekwalkhalaf@gmail.com. ORCID: http://orcid.org/0000-0003-1188-0632

Рубан О. А., докторка фармац. наук, професорка, завідувачка кафедри заводської технології ліків, Національний фармацевтичний університет Міністерства охорони здоров’я України. E-mail: ruban elen@ukr.net. ORCID: http://orcid.org/0000-0002-2456-8210

Грудько В. О., кандидат фармац. наук, доцент кафедри фармацевтичної хімії, Національний фармацевтичний університет Міністерства охорони здоров'я України. E-mail: 431230@ukr.net

Гербіна Н. А., кандидатка фармац. наук, доцентка кафедри заводської технології ліків, Національний фармацевтичний університет Міністерства охорони здоров'я України. E-mail: n.a.gerbina@gmail.com. ORCID: http://orcid.org/0000-0001-9826-7552

Гвоздик О. В., магістрант кафедри фармацевтичної хімії, Національний фармацевтичний університет Міністерства охорони здоров'я України

\section{Сведения об авторах:}

Алхалаф Малек В. А., аспирант кафедры заводской технологии лекарств, Национальный фармацевтический университет Министерства здравоохранения Украины. E-mail: malekwalkhalaf@gmail.com. ORCID: http://orcid.org/0000-0003-1188-0632 Рубан Е. А., доктор фармац. наук, профессор, заведующая кафедрой заводской технологии лекарств, Национальный фармацевтический университет Министерства здравоохранения Украины. E-mail: ruban_elen@ukr.net.

ORCID: http://orcid.org/0000-0002-2456-8210

Грудько В. А., кандидат фармац. наук, доцент кафедры фармацевтической химии, Национальный фармацевтический университет Министерства здравоохранения Украины. E-mail: 431230@ukr.net

Гербина Н. А., кандидат фармац. наук, доцент кафедры заводской технологии лекарств, Национальный фармацевтический университет Министерства здравоохранения Украины. E-mail: n.a.gerbina@gmail.com. ORCID: http://orcid.org/0000-0001-9826-7552 Гвоздик О. В., магистрант кафедры фармацевтической химии, Национальный фармацевтический университет Министерства здравоохранения Украины 